Available online: https://journals.researchsynergypress.com/index.php/ijebce/

International Journal of Entrepreneurship, Business and Creative Economy (IJEBCE)

ISSN 2775-3085 (Online) | 2775-3107 (Print)

Volume 1 Number 1 (2021): 13-24

\title{
Factors Affecting Students' Perception of Online Shopping
}

\author{
Anushia Chelvarayan'1, Chew Sin Jie', Yeo Sook Fern' ${ }^{1}$ \\ ${ }^{1}$ Faculty of Business, Multimedia University, Melaka, Malaysia
}

\begin{abstract}
Within this research we want to study about the factors affecting students' perception of online shopping, since in this time the internet is being used as the primary source to provide information and its application has been vastly exploited for our own conveniences. Derived from our literatures, we confirmed that the variables: (1). Convenience, (2). Ease of use, (3). Usefulness, (4). Privacy and security, and (5). Saves money, time and effort, are the main factors in affecting a student to pursue with online purchases. We use the Technology Acceptance Model (TAM) and the Theory of Planned Behaviour (TPB) as the theoretical foundations, and 200 questionnaire respondents from a private university in Malaysia as our samples. Further, we use the Descriptive Analysis, the Reliability Analysis and the Multiple Regression Analysis to process the data. We believe that the data collected is highly beneficial and valuable to students, supervisors, academics, researchers, learning institutions, business organisations and the government as we are able to gauge and understand the factors affecting students' perception of online shopping. However, our theoretical framework limiting us to focus on abovementioned four variables, and we will open several possibilities for future researches, whereby one can focus more on other influencing factors such as trust, risk, complexity, pervasive technology usage, and tech-savvy future generations.
\end{abstract}

Keywords: Online shopping; perception

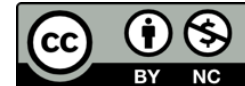

This is an open access article under the CC-BY-NC license.

\section{INTRODUCTION}

Online shopping has become an important part of our daily lives. With the rapid growth of online technology, the advantages of the online platform can be leveraged by developing the appropriate shopping tools. What more, with the recent pandemic worldwide, online shopping has become an easier way to enable everyone to access their shopping from a click of a mouse. Online shopping is an action or activity of purchasing goods and services through the internet. People go online, $\log$ in to a shopping website, purchase goods and services, and make delivery arrangements. The buyer usually pays with a credit or debit card or through a third party online transfer or cash upon delivery of the goods and services. Online shopping has grown popular in recent years, primarily because people look for its convenience, ease of use, usefulness, and can save money, time, and effort. Online shopping has also attracted the attention of students in this generation. The main purpose of this research is to study the factors affecting students' perception on online shopping. Online shopping gradually has replaced physical shopping due to limited time, traffic jam, crowded and etc. Therefore, online shopping is becoming more popular as it can be easily accessed in everyday life. From the consumers' perspective, online shopping has a lot of advantages compared to physical shopping as it can save money, time, and effort (Liu et al., 2012, Kim et al., 
International Journal of Entrepreneurship, Business and Creative Economy (IJEBCE), Vol. 1 (1), 13-24

Factors Affecting Students' Perception of Online Shopping

Anushia Chelvarayan, Chew Sin Jie, Yeo Sook Fern

2008). We believe these benefits have an important and significant effect on the behavior of consumers towards online shopping (Delafrooz et al., 2011).

\section{LITERATURE REVIEW}

From the 1990s, online shopping is getting more popular, the number of consumers has been increasing on purchasing various products through the Internet (Zhou, and Zhang and Dai, 2007). According to 2017 Malaysia's Top E-Commerce Website (2017), the top website that people do online shopping is Lazada in Malaysia, with 30,300,000 visitors per month in June 2017, followed by 11street Malaysia with 10,200,000 visitors per month, followed by Lelong.my, with 6,200,000 visitors (Top e- commerce sites in Malaysia 2017, 2017). Rohm and Swaminathan (2004) also show that online shopping is an infrastructure that makes it easier for customers to search, contrast, and access relevant information. Therefore, online shopping has become a section of people's daily lives (Noort, Kerkhof, and Fennis, 2008).

Past research has found that "Convenience" is an important variable of online shopping (Clemes et al., 2014). Burke (1998) pointed out in his research that convenience is the most regularly cited reason for online purchasing. According to Delafrooz, Khatibi, and Paim (2010), convenience is the reason for influencing the ability of customers to shop online. The major motivation for online purchasing is more convenient than shopping in traditional stores (Delafrooz et al., 2009). Malaysian Internet users who do purchasing at online shops seek opportunities such as convenience, cost savings, low prices, easy method to search for information, and 24-hour service (Zuriahti Azura, 2010). Consumers' perceptions of interest include convenience, company name, freedom of choice, information enrichment, and familiar homepage design, which have an important relationship with attitudes on online shopping (Shwu-Ing, 2003). Furthermore, convenience variables are significantly related to purchase behavior through online advertising (Hasan and Rahim, 2004). Convenience includes factors such as time, energy, and anxiety (Cho and Sagynov, 2015) and the ability to compare many products in one place at any time (Hung et al., 2014). Besides that, compared with physical stores, it is more convenient for customers to feel more convenient when shopping online (Delafrooz et al., 2010). The major opportunity for online purchasing is that customers can buy at any time of the day or where (McKinney, 2004; Kim and Kim, 2004 as cited in Delafrooz, Paim, \& Khatibi (2010).

Later, the "Ease of use", as our second variable, is the degree to which people think that using a new technique is not laborious, according to the studies of Davis (1989), Davis, Warshaw, and Bagozzi (1989). When this environment was applied to online shopping, the ease of use means that consumers think that spending the least amount of money and effort on the Internet (Davis, 1989). Perceived ease of use is a standard that people consider, to be honest, that is, they can use technology or systems to find information without any effort (Davis, 1989). Perceived usefulness is theconsumer's perception of the results of online purchasing experiences, and perceived ease of use is their perception of the process leading to the ultimate online shopping result (Monsuwe, Ruyter, and Dellaert, 2004). Selamat, Jaafar, and Boon (2009) clarify that consumers prefer to have a more simple and user-friendly system when shopping online. On the opposite, if users realize that using the site is difficult and unfriendly for them, the intention to buy online will be reduced (Green, Pearson, and Pearson, 2007; Cheng and Yee, cited in 2014). Oentario et al. (2017) showed that ease of use has a direct and important effect on the attitudes of the consumers. Furthermore, it has been 
International Journal of Entrepreneurship, Business and Creative Economy (IJEBCE), Vol. 1 (1), 13-24

Factors Affecting Students' Perception of Online Shopping

Anushia Chelvarayan, Chew Sin Jie, Yeo Sook Fern

found that researchers have drawn out that the ease of use had a good relationship with online purchase intentions through past research. There is a positive impact between perceived ease of use and willingness to make online purchases. The ease of use of technology and the online purchasing experience satisfaction are important for online user predictions (Ramayah \& Ignatius, 2005).

Teck (2002) pointed out that usefulness as the main factor in online shopping. Davis (1989) found that the relative strength that compared between the usefulness to usage relationship, and the ease of use to usage relationship. But according to those studies, the usefulness is more important factor than the ease of use to the usage, since this might change the consumers behaviors and attitudes. The variable of "Usefulness" is the individual's perception to consider that the use of new technologies will enhance their performance (Davis, 1993). We can say that internet can improve customers' performance or productivity, including their own shopping experience (Monsuwe, Ruyter and Dellaert, 2004). The "Usefulness" of perception was associated with the result of the shopping experience (Monsuwe et al., 2004). Shadkam, Kavianpour, Honarbakhsh, and Wan (2013), once more highlighted that "Usefulness" is more effective than "Ease of use" in shopping willingness. There are five indicators that can be used to measure the "Usefulness" of perception: fast, save time, ease, reduce cost, and overall usefulness (Renny, Guritno and Siringoringo, 2013).

Another factor affecting online shopping is "Security and privacy". Ramayah, Teck, Aafaqi, and Dahlan (2003) pointed out that the main obstacles to adopt electronic retail are the customer beliefs in security and privacy problems, and to solve this issue we require improving technology. Consumers are reluctant to conduct Internet transactions, in part because of barriers to purchase on the internet, security, and privacy issues (Grandinetti, 1996; Udo, 2001). Our experiences showed that the internet user is very emphasized their privacy and security, because they need to feel secure and protect their personal information. However, privacy was not solely associated with the company's decision to process consumer data, because of the presence of third-party consumer data that might misissue consumer data, such as identity theft and hacker. Salim (2000) refers that in the future, hackers will not only inside the company, and it still may come from other places that are external or unrecognizable. According to Guo Xiaoying, Guo Cuiling, and Liu Min (2012), security means that online shopping sites can protect their consumers' private information from any potential threats from the information that unauthorized use in the business deal. The primary part is about transaction security and online data, and the second part is based on user authentication (Guo, 2012). Privacy and security issues are the most important factors to keep trust in online transactions and the website (Chellappa, 2002). To appease this issue, Yu and Abdulai, (2000) showed that the government's role to promote the growth of Internet shopping must be inline with the consumer security protection.

The last factor we discuss is " Saves money, time and effort ". Comparing to the traditional shopping, which was considered to take more time, online shopping was considered attractive (Alreck and Settle, 2002). Besides that, Malaysian Internet users who shop online seek opportunities like lower prices, convenience, cost savings, easy methods to search the information, and 24-hour service (Zuriahti Azura, 2010). It's very convenient to provide information at the same time because users can save time and get product information such as comments on specific products before purchasing any products (Muda, Mohd, and Hassan, 2016). Consumer perceived 
International Journal of Entrepreneurship, Business and Creative Economy (IJEBCE), Vol. 1 (1), 13-24

Factors Affecting Students' Perception of Online Shopping

Anushia Chelvarayan, Chew Sin Jie, Yeo Sook Fern

benefits comprised their need or advantage for online shopping, including convenience, easy access to information, and save time and price advantages (Shwu- Ing, 2003). According to Azura (2010) and Ho (2013), the most popular benefits shown in past studies are convenience, low prices, easy access to information, 24-hour service, and cost savings. Time-saving and convenience are the most significant reasons for customers to purchasing at online (Chen, Hsu \& Lin, 2010). The research of Ngugi (2014) shows that products are easy to compare, time-saving, convenience, and price advantage are the reasons for adopting purchasing online. Online shoppers usually spend less time than physical shoppers at a retail store due to many time-consuming activities related to traditional retail stores such as long queues, parking the car, driving to a store, and more (Rohm and Swaminathan, 2004; Bellman et al., 1999). In fact, most consumers emphasize saving money and time when shopping online (Horrigan, 2008).

Entailing the abovementioned factors, we adopt the Technology Acceptance Model (TAM) and the Theory of Planned Behaviour (TPB) into our theoretical foundations. The Technology Acceptance Model (TAM) has been developed by Davis in 1989. It has relied on the theory of reasoned action (TRA), and it has been the influential technology acceptance model (Neil Charness, 2016). The two of the major factors, which are ease of use and usefulness, can access the acceptability of an information system. This model has been widely praised and used by popular, although many models have been recommended to describe the relationship in the information systems field. Davis defines the usefulness of perception as the subjective probability of the targeted user, using a specific application framework can enhance his or her life or work performance. Perceived ease of use (EOU) can be defined as the extent to which the target system a prospective user to be effortless. Their ease of use and usefulness are expected to influence the individuals' attitudes of using the system, and they also illustrate the different intents of using the system. TAM also believes that the synergy between ease of use and usefulness, which also suggests that the ease with which the system is used can affect their perception of the system's usefulness (Vijayasarathy, 2003).

The Theory of Planned Behavior (TPB) began in 1980 with the Theory of Reasoned Action (TRA) in 1980 as well, which aims to forecast an intention of an individual to undertake some behaviors at a certain time and place. The intention is presented to describe the factors that influence behavior. The theory's purpose is to describe all of the behaviors, which can be controlled by people themselves. The major element of the model is behavioral intention. The behavioral intention was affected by the behavior attitude towards the probability of the expected outcome and the subjective assessment of the risk and benefit of the result. This shows how people will try to implement many of the tasks in the plan to perform the behavior (Ajzen, 1991). The theory of planned behavior (TPB) has made a variety of innovations by increasing the structure of perceptual, behavioral control (Ajzen 1991). The use and satisfaction theory to addresses the motivation and satisfaction with the use of communication media or technology and to support acceptance and behavior technology (Katz, Blumler and Gurevitch 1973). How strong an individual's attempt to do this is and how well the person controls the behavior will affect whether he or she is involved in the behavior. 
International Journal of Entrepreneurship, Business and Creative Economy (IJEBCE), Vol. 1 (1), 13-24

Factors Affecting Students' Perception of Online Shopping

Anushia Chelvarayan, Chew Sin Jie, Yeo Sook Fern

\section{RESEARCH METHOD}

The dependent and independent variables provided in our research framework, in Figure 1, shows the relationship between these two variables. Research framework has been set up based on the relationships between "Students' Perception on Online Shopping" as dependent variable and "Convenience", "Ease of use", "Usefulness", "Privacy and security", and "Save money, time and effort" as independent variables. The independent variables are used as intermediary variables to measure factors affecting students' perception of mobile learning.

Based on the research objectives, this paper will be analysingfive different hypotheses derived from the research framework. These five hypotheses are to examine the significant relationship between convenience, ease of use, usefulness, privacy and security and save money, time and effort with students' perception of online shopping. They are:

H01: There is no a significant relationship between convenience and students' perception of online shopping.

H02: There is no a significant relationship between ease of use and students' perception of online shopping.

H03: There is no a significant relationship between usefulness and students' perception of online shopping

H04: There is no a significant relationship between privacy and security and students' perception of online shopping

H05: There is no a significant relationship between save money, time and effort, and students' perception of online shopping

The population used in this study is a group of students from a Private Higher Learning Institution in Malaysia. With the total number of respondents is 200 students, we use non-probability (Convenience) sampling; whereby we selected samples based on subjective judgment, because of its speed, cost- effectiveness, and availability. We use questionnaires distributed through face to face and electronic form. Our Reliability Analysis measures the reliability of variables of the research, by using the Cronbach's Alpha values to estimate the significance. Table below shows the values for dependent and independent variables. From the table below, the variables range from 0.719 to 0.817 . Overall, if the Cronbach's Alpha value exceeding 0.7 is count as acceptable and measurement is good when the value is over 0.8 . Therefore, all variables of this research are being accepted due to all of them have the Cronbach Alpha value that is above 0.7.

In order to analyze the demographic data, the concepts captured under this study, and their relationships, Statistical Package for the Social Sciences (SPSS) is used in this study. The data analysis method used is shown below.

Table 1: Cronbach's Alpha Value

\begin{tabular}{|l|l|c|c|}
\hline No & Variable Item & No. Of Item & Cronbach's Alpha \\
\hline 1 & Online Shopping & 27 & 0.817 \\
\hline 2 & Convenience & 4 & 0.782 \\
\hline 3 & Ease of Use & 5 & 0.768 \\
\hline
\end{tabular}


International Journal of Entrepreneurship, Business and Creative Economy (IJEBCE), Vol. 1 (1), 13-24 Factors Affecting Students' Perception of Online Shopping Anushia Chelvarayan, Chew Sin Jie, Yeo Sook Fern

\begin{tabular}{|l|l|c|c|}
\hline 4 & Usefulness & 5 & 0.725 \\
\hline 5 & Privacy and Security & 5 & 0.719 \\
\hline 6 & Save Money, Time and Effort & 5 & 0.744 \\
\hline
\end{tabular}

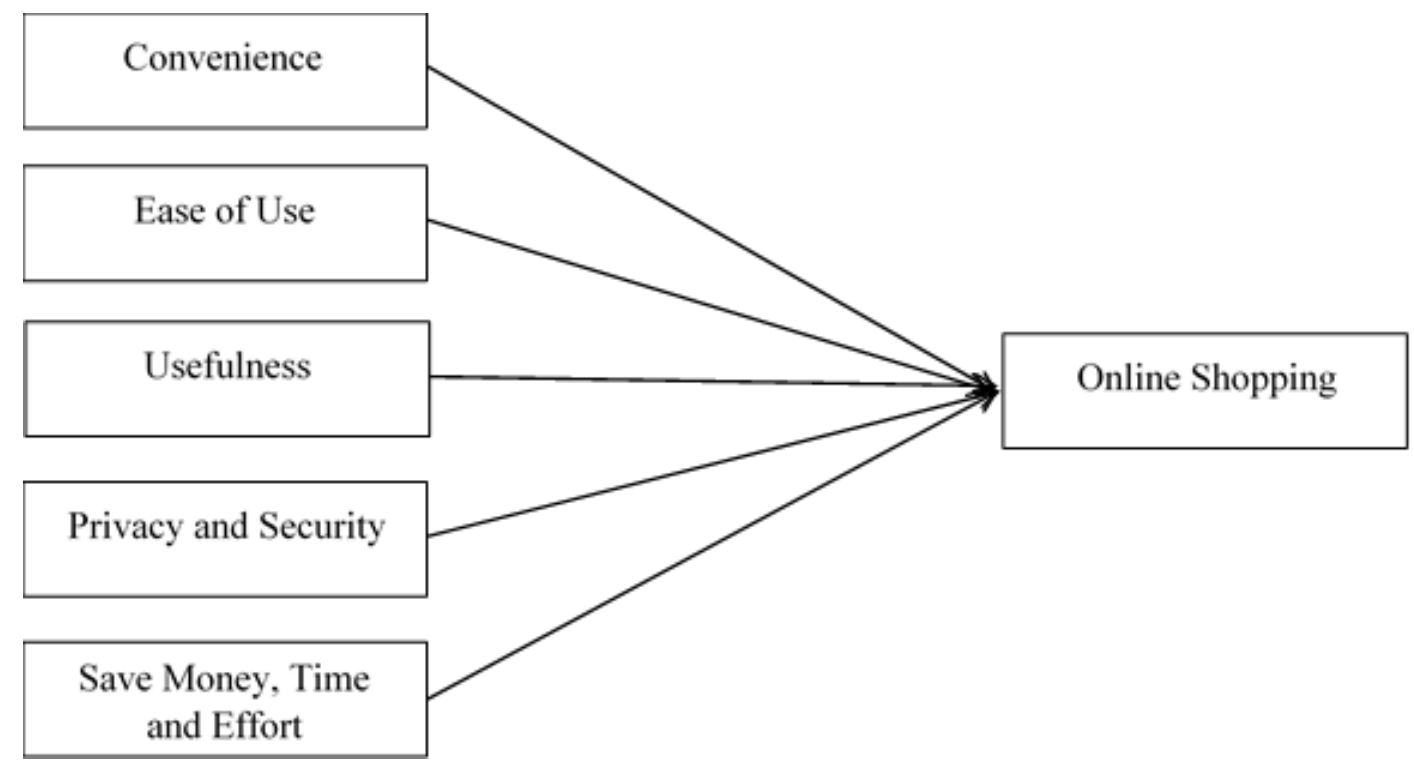

Figure 1: Research Framework (Developed for this research)

\section{FINDINGS AND DISCUSSION}

The findings are presented in the tables below to provide a clear understanding. The hypotheses developed have also been tested and summarized as follows:

Table 2: Demographic Information

\begin{tabular}{l|l|l|l}
\hline Variables & & Frequency & Percentage \\
\hline Gender & Male & 80 & 40.0 \\
& Female & 120 & 60.0 \\
\hline Age & $18-20$ & 40 & 20.0 \\
& $21-23$ & 152 & 76.0 \\
& $24-26$ & 8 & 4.0 \\
& 27 and above & 0 & 0 \\
\hline Education level & Foundation & 27 & 13.5 \\
& Diploma & 35 & 17.5 \\
& Degree & 138 & 69.0 \\
& Master/PhD & 0 & 0 \\
\hline Monthly Pocket & Less than RM500 & 7 & 3,5 \\
Money & RM500-RM750 & 12 & 6.0 \\
& RM750-RM1000 & 141 & 70.5 \\
& More than RM1000 & 40 & 20.0 \\
\hline Weekly Online & Once a week & 167 & 83.5
\end{tabular}


International Journal of Entrepreneurship, Business and Creative Economy (IJEBCE), Vol. 1 (1), 13-24

Factors Affecting Students' Perception of Online Shopping

Anushia Chelvarayan, Chew Sin Jie, Yeo Sook Fern

Purchase

2-3 times a week More than three times a week

14.5

2.0

Table 2 summarises the demographic information collected for this research, with a total of 200 respondents who are students from a Private Higher Learning Institution.

Table 3: Reliability Analysis

\begin{tabular}{lcc}
\hline Variables & Number of Item & Cronbach's Alpha \\
\hline Convenience (CON) & 4 & 0.782 \\
Ease of Use (EOU) & 5 & 0.768 \\
Usefulness (USE) & 5 & 0.725 \\
Privacy and Security (PNS) & 5 & 0.719 \\
Save Money, Time \& Effort (SMTE) & 5 & 0.744 \\
Online Shopping & 7 & 0.817 \\
\hline
\end{tabular}

Cronbach's Alpha for each variable is shown in Table 3. All the independent variables have the same number of items, which is five items with the exception of convenience, i.e. only four items. The dependent variable in this research has seven items. The result of Cronbach's Alpha showed all above 0.7 and means all the variables are acceptable in this study. The highest Cronbach's Alpha of independent variables is convenience, which is 0.782 , ease of use is 0.768 , save money, time and effort are 0.744 , usefulness is 0.725 , and privacy and security is 0.719 . At the same time, the dependent variable of online shopping showed the value of Cronbach's Alpha is 0.817 .

Table 4: Coefficients

Unstandardized Coefficients Standardized Coefficients

\begin{tabular}{lccccc}
\hline Model & B & Std.Error & Beta & t & Sig \\
\hline Constant) & 1.666 & 0.552 & & 3.019 & 0.003 \\
CON & 0.416 & 0.089 & 0.388 & 4.657 & 0.000 \\
EOU & -0.523 & 0.118 & $-0,456$ & -4.445 & 0.000 \\
USE & 0.219 & 0.126 & 0.194 & 1.740 & 0.083 \\
PNS & -0.401 & 0.107 & -0.349 & -3.748 & 0.000 \\
SMTE & 0.812 & 0.104 & 0.763 & 7.830 & 0.000 \\
\hline
\end{tabular}

Table 4 shows save money, time, and effort has the highest beta value in the unstandardized coefficient of 0.523. This means saving money, time, and effort is the strongest independent variable to influence students' perception of online shopping. The lowest beta value in the unstandardized coefficient is usefulness, which is 0.219 . Table 4 shows the result of coefficients 
analyzed by SPSS. Table 4 demonstrates the relationship between dependent and independent variables through multiple linear regression analysis. The hypothesis is supported if the $p$-value (significance level) does not exceed 0.05 . In this research, five independent variables are tested, and four of them are significant. The four independent variables have the same significant value of 0.000, which are Convenience, Ease of Use, Privacy and Security, and Save Money, Time, and Effort. Lastly, the only independent variable whose significant value exceeds 0.05 is usefulness $(0.083)$.

Table 5: Hypotheses summary

\begin{tabular}{lcc}
\hline \multicolumn{1}{c}{ Hypotheses } & P-value & Findings \\
\hline $\begin{array}{l}\text { H1: There is a significant relationship } \\
\text { between convenience and students' } \\
\text { perception of online shopping. }\end{array}$ & 0.000 & Supported \\
$\begin{array}{l}\text { H2: There is a significant relationship } \\
\text { between ease of use and students' perception } \\
\text { of online shopping. }\end{array}$ & 0.000 & Supported \\
$\begin{array}{l}\text { H3: There is a significant relationship } \\
\text { between usefulness and students' perception } \\
\text { of online shopping }\end{array}$ & 0.083 & Not \\
$\begin{array}{l}\text { H4: There is a significant relationship } \\
\text { between privacy and security and students' } \\
\text { perception of online shopping }\end{array}$ & & Supported \\
H5: There is a significant relationship \\
between save money, time and effort, and \\
students' perception of online shopping.
\end{tabular}

Table 5 shows the result of coefficients analyzed by SPSS. If the significant value (also known as the p-value) does not exceed 0.05, the hypothesis is supported. According to the table above, four independent variables are significant among the five independent variables. Convenience $(0.000)$, ease of use (0.000), privacy and security $(0.000)$, and save money, time and effort (0.000) are significant in this research. In contrast, usefulness (0083) is insignificant in the research as it exceeds 0.05 .

\section{CONCLUSION}

This research was to investigate factors affecting students' perception on online shopping. This research will be the future studies for online shopping in Malaysia especially during this global pandemic challenge faced by the entire world. The findings of the research could contribute to the development of online shopping platforms especially for students' market. This finding is useful for online platform or application developers, whereby they can use the findings from this research to enhance their existing platforms or develop new platforms specially dedicated to students.

Moreover, this research will not only bring the advantage to online sellers, but it will also help any company and organization that might transform their business into an online system. This 
International Journal of Entrepreneurship, Business and Creative Economy (IJEBCE), Vol. 1 (1), 13-24

Factors Affecting Students' Perception of Online Shopping

Anushia Chelvarayan, Chew Sin Jie, Yeo Sook Fern

research can be a guide for them to get a smooth start in e-commerce and develop their function of operation in the future if the students are their target market.

In addition, online sellers can eliminate the redundant process of online purchasing and enhance the quality of online purchasing, such as enhancing the ordering process, which can generate customer search products and place their order in simple few steps. Besides that, the online seller can also enhance their privacy and security system to make the consumer feel more secure when shopping online. Therefore, by undertaking online shopping, consumers believe they can save a lot of time and effort.

However, there are some limitations that should be considered when conducting research. Firstly, the sample size in this research was small, with only 200 respondents. Therefore, the findings might not be able to provide the perception of online shopping among students across Malaysia's universities.

Secondly, the data cannot be collected smoothly in a short period of time. This is because most of the respondents are not willing or do not have time to fill up the questionnaire. This makes data collection becomes difficult for researchers.

Further research is recommended to obtain a larger sample size from students who are from many universities in Malaysia. A larger sample size allows the researchers to draw a stronger conclusion about the relationship between the variables. The questionnaires should be distributed to more than one location to increase the accuracy of the data obtained. In conclusion, students' perceptions of online shopping are clearly shown in this research. Therefore, mobile learning developers can attract more users by developing better user-accepted mobile learning systems and promoting their benefits to students.

\section{ACKNOWLEDGEMENT}

Firstly, I would like to express my deepest appreciation to my fellow researchers Dr. Yeo Sook Fern and Ms. Chew Sin Jie for their continuous support and encouragement to ensure the completion of this project. My special thanks to Ms. Chew, who ensured that this research, as part of her Final Year Project was completed with due diligence and in a timely manner. Not forgetting, a special note of appreciation to Dr. Santi Rahmawati and her entire organizing committee of the 4th International Conference on Entrepreneurship Studies, Business, Economy, and Management Science (4th ESBEM) for giving me an opportunity to present and publish in this prestigious, well known International Conference.

\section{REFERENCES}

Ajzen, I. (1991). The theory of planned behavior. Organizational Behavior And Human Decision Processes, vol. 50, pp. 179-211.

Alreck, P. and Settle, R. (2002). The hurried consumer: time-saving perceptions of internet and catalogue shopping. Journal of Database Marketing, 10(1), pp. 25-35. In Business Source Complete (OUM digital collection).

Bellman Steven, Lohse Gerald H, Johnson Eric J.(1999). Predictors of online buying behavior.

Commun ACM;42(12):32-8.

Burke, Raymond R. (1998). Do you see what I see? The future of virtual shopping. Journal of the Academy of Marketing Science, 25, 352-360.

Chellappa, R. (2002). Customers' trust in electronic commerce transactions: The role of perceived privacy and perceived security. Atlanta: Emory University.

Chen, J. H., Xie, X. Y., \& Jing, F. X. (2011). The security of shopping online. International Conference on Electronic \& Mechanical Engineering and Information Technology, 4693-4696.

Chen, Y. H., Hsu, I. C., \& Lin, C. C. (2010). Website attributes that increase consumer purchase intention: A conjoint analysis. Journal of Business Research, 63(9-10), 1007-1014.

Cheng, B. L., \& Yee, S.W. (2014). Factors Influencing Consumers' Online Purchase Intention: A Study 
International Journal of Entrepreneurship, Business and Creative Economy (IJEBCE), Vol. 1 (1), 13-24

Factors Affecting Students' Perception of Online Shopping

Anushia Chelvarayan, Chew Sin Jie, Yeo Sook Fern

among University Students in Malaysia. International Journal of Liberal Arts and Social Science, 2(8), 121-133. http://doi.org/10.5539/ass.v10n9p18

Cheng, B. L., \& Yee, S.W. (2014). Factors Influencing Consumers' Online Purchase Intention: A Study among University Students in Malaysia. International Journal of Liberal Arts and Social Science, 2(8), 121- 133. http://doi.org/10.5539/ass.v10n9p18

Cheung M.K., C. (2015) How Online Social Interactions Influence Customer Information Contribution Behavior in Online Social Shopping Communities: A Social Learning Theory Perspective. Journal of the Association for Information Science and Technology, 66(12), 25112521

Chiang,Kuan-Pin.(2001).Effects of price, product type, and convenience on consumer intention to shop online. In Ram Krishnan and Madhu Viswanathan (Eds.), Proceedings of AMA Winter Educators'Conference, Vol. 12, pp. 163-169. Chicago: American Marketing Association.

Chiu, C.-M., Lin, H.-Y., Sun, S.-Y. and Hsu, M.-H. (2009), “Understanding customers' loyalty intentions towards online shopping: an integration of technology acceptance model and fairness theory", Behavior \& Information Technology, Vol. 28 No. 4, pp. 347-60. In EBSCOhost (OUM digital collection).

Chiu, C.M., Wang, E.T., Fang, Y.H. and Huang, H.Y. (2014), "Understanding customers' repeat purchase intentions in B2C e-commerce: the roles of utilitarian value, hedonic value and perceived risk", Information Systems Journal, Vol. 24 No. 1, pp. 85-114.

Cho, Y.C. and Sagynov, E. (2015), "Exploring factors that affect usefulness, ease of use, trust, and purchase intention in the online environment", International Journal of Management \& Information Systems, Vol. 19 No. 1, pp. 21-36.

Clemes, M.D., Gan, C. and Zhang, J. (2014), "An empirical analysis of online shopping adoption in Beijing, China", Journal of Retailing and Consumer Services, Vol. 21 No. 3, pp. 364-375.

Chua, P.H (Adeline), Ali.Khatibi \& Hishamuddin bin Ismail (2006). E-Commerce: A Study on Online Shopping in Malaysia. J. Soc. Sci., 13(3): 231-242 (2006) [Online].

Davis, F.D., Bagozzi, R.P., \& Warshaw, P.R. (1989). User acceptance of computer technology: a comparison of two theoretical models. Management Science, Vol. 35, pp. 982-1003.

Davis, F. D. (1993). User acceptance of information technology: system characteristics, user perceptions and behavioral impacts. International Journal of Man-Machine Studies , 38 (3), 475-487.

Davis, F. D. (1989). Perceived usefulness, perceived ease of use, and user acceptance of information technology. MIS Quarterly , 13 (3), 319-340.

Delafrooz, N., Paim, L. H., \& Khatibi, A. (2010). Students' Online Shopping Behavior: An Empirical Study. Journal of American ScienceJournal of American Science, 6(1), 137-147.

Delafrooz, N., Paim, L.H. and Khatibi, A. (2011), "Understanding consumer's internet purchase intention in Malaysia", African Journal of Business Management, Vol. 5 No. 3, pp. 2837-2846.

Delafrooz, Narges, Laily H. Paim1*, Sharifah Azizah Haron1, Samsinar M. Sidin2 and Ali Khatibi3 (2009). Factors Affecting Students' Online Shopping Attitude and Purchase Intention. PhD thesis, Universiti Putra Malaysia. [Online]. Available: http://academicjournals.org/article/article1380535988_Delafrooz\%20et\%20al..pdf [2013, July 20].

Guo, X., Ling, K. C., \& Liu, M. (2012). Evaluating Factors Influencing Consumer Satisfaction towards Online Shopping in China. Asian Social Science, 8(13), 40-50. https://doi.org/10.5539/ass.v8n13p40

Hasan, H., \& Rahim, S. A. (2004). Factors affecting online purchasing behavior. Journal of Communication, $24, \quad 1-19 . \quad$ [Online]. Available: http://sssums.files.wordpress.com/2007/11/factors-affecting-online purchasingbehavior.pdf [2013, Sept 22].

Horrigan John B. (2008). Online shopping. Washington, DC: Pew Internet Life \& American Project. Horrigan, J. B. (2009, February 15). Online Shopping: Convenient But Risky. Retrieved from 
International Journal of Entrepreneurship, Business and Creative Economy (IJEBCE), Vol. 1 (1), 13-24 Factors Affecting Students' Perception of Online Shopping

Anushia Chelvarayan, Chew Sin Jie, Yeo Sook Fern

pewresearch.org: http://pewresearch.org/pubs/733/onlineshopping

Hung, S.Y., Chen, C.C. and Huang, N.H. (2014), "An integrative approach to understanding customer satisfaction with e-service of online stores", Journal of Electronic Commerce Research, Vol. 15 No. 1, pp. 40-57.

Kim, D.J., Ferrin, D.L. and Rao, H.R. (2008), "A trust-based consumer decision-making model in electronic commerce: the role of trust, perceived risk, and their antecedents", Decision Support Systems, Vol. 44 No. 2, pp. 544-564.

Lai, J.Y. (2014), "E-SERVCON and E-Commerce success: applying the DeLone \& McLean Model”, Journal of Organizational and End User Computing, Vol. 26 No. 3, pp. 1-22.

Liu, M.T., Chu, R., Wong, I.A., Zúñiga, M.A., Meng, Y. and Pang, C. (2012), "Exploring the relationship among affective loyalty, perceived benefits, attitude, and intention to use co-branded products", Asia Pacific Journal of Marketing and Logistics, Vol. 4 No. 4, pp. 561-582

Mudaa, M, Mohdb, R., \&Hassan, S. (2016). Online purchase behavior of generation Y in Malaysia: procedia economics and finance, 37, $292-298$.

Monsuwe, T. P., Dellaert, B. G., \& Ruyter, K. d. (2004). What drives consumers to shop online? A literature review. International Journal of Service Industry Management , 15 (1), 102-121.

Neil Charness, Walter R. Boot. (2016) in Handbook of the Psychology of Aging (Eighth Edition).

Ngugi, K. (2014). Factors influencing online shopping adoption in Kenya: A case of Westlands district. University of Nairobi.

Oentario, et al. (2017). Pengaruh usefulness, ease of use, risk terhadap intention to buy online patisserie melalui consumer attitude berbasis media sosial di Surabaya. Jurnal Manajemen Pemasaran, 11(1), 26 - 31. ISSN 1907-235X.

Ramayah, T., Aafaqi, B., \& Jantan, M. (2003). Internet usage among students of institution of higher learning: the role of motivational variables. The Proceedings of the 1st International Conference on Asian Academy of Applied Business Conference, Sabah, Malaysia 10-12 July, 2003.

Ramayah, T., Dahlan, N., Teck., T.K., \& Aafaqi, B. (2003). Perceived web security and web-based online transaction intent, Multi-Media Cyberspace Journal, vol.1 [Online] Available: http://cyberscape.mmu.edu.my/.

Ramayah, T., \& Ignatius, J. (2005). Impact of perceived usefulness, perceived ease of use, and perceived enjoyment on intention to shop online. ICFAI Journal of Systems Management, 3(3), 36-51.

Renny, Guritno, S., \& Siringoringo, H. (2013). Perceived Usefulness, Ease of Use, and Attitude Towards Online Shopping Usefulness Towards Online Airlines Ticket Purchase. Procedia Social and Behavioral Sciences, 81, 212-216. http://doi.org/10.1016/j.sbspro.2013.06.415

Rohm, A. J., \& Swaminathan, V. (2004). A Typology of Online Shoppers Based on Shopping Motivations. Journal of Business Research, 57, 748-757.

Salim, B., Tayib, M., \& Abidin, S. (2000). Computer crime and security a survey of financial institution in Malaysia: The Proceedings of International Conference On Electronic Commerce,Emerging Trends in E-Commerce, Kuala Lumpur, Malaysia, November, Multi-Media University.

Selamat, Z., Jaafar, N., \& Boon, O. H. (2009). Technology Acceptance in Malaysian Banking Industry. European Journal of Economics. Finance and Administrative Sciences, 17.

Shadkam, M., Kavianpour, S., Honarbakhsh, S., \& Wan, H. L. (2013). Antecedents of Consumers' Intention to Shop online. Australian Journal of Basic and Applied Sciences, 7(13), 190-197.

Shwu-Ing $\mathrm{Wu}$, (2003). The relationship between consumer characteristics and attitude toward online shopping", Marketing Intelligence \& Planning, Vol. 21 Iss: 1, pp.37 - 44 - In Emerald (OUM digital collection).

Swaminathan, V., Lepkowska-White, E. and Rao, B. P. (1999). Browsers or Buyers in Cyberspace? An Investigation of Factors Influencing Electronic Exchange. Journal of ComputerMediated Communication, 5(2).

Teck, T.K. (2002). The Impact of Perceived Web Security, Perceived Privacy Loss, Perceived 
International Journal of Entrepreneurship, Business and Creative Economy (IJEBCE), Vol. 1 (1), 13-24

Factors Affecting Students' Perception of Online Shopping

Anushia Chelvarayan, Chew Sin Jie, Yeo Sook Fern

Usefulness and Perceived Ease of Use on the Web-Based Online Transaction Intent, MBA Thesis, School Of Management, Universiti Sains Malaysia, Penang.

Top e-commerce sites in Malaysia 2017. (2017, November 14). Retrieved from https://aseanup.com/top-e-commerce-sites-malaysia/

Udo, G.J. (2001). Privacy and security concerns as major barriers for e-commerce: a survey study. Information Management \& Computer Security, vol. 9, pp. 165-174.

Vijayasarathy, L. R. (2002). Internet taxation, privacy and security: Opinions of the taxis and legislated . Quarterly Journal of Electronic Commerce , 83-104.

Vijayasarathy L.R. (2003). Predicting consumer intentions to use online shopping: the case for an augmented technology acceptance model. Information and Management (August).

$\mathrm{Yu}$, C.M., \& Abdulai, D.N. (2000). E-commerce and the new economy: The Proceedings of International Conference On Electronic Commerce, Emerging Trends in E-Commerce, Kuala Lumpur, Malaysia, November, Multi-Media University.

Zeithaml VA 1988. Consumer perceptions of price, quality, and value: A means-end model and synthesis of evidence. Journal of Marketing, 52(03): 2-22.

Zhou, L., Dai, L. W., \& Zhang, D. S. (2007). Online shopping acceptance model- a critical survey of consumer factors in online shopping. Journal of Electronic Commerce Research, 8(1), 41-42.

Zuriahti Azura, R. (2010). The Influence of the Intention Online Purchase Among Universiti Kuala Lumpur, Malaysian Institute of Information Technology Lecturer's and Staff's. Unpublished Final Year Project, Malaysian Institute of Information Technology, Universiti Kuala Lumpur, Malaysia. 